\title{
Young people's attitudes towards inter- ethnic and inter-religious socializing, courtship and marriage in Indonesia
}

\author{
Lyn Parker, Chang-Yau Hoon and Raihani
}

\begin{abstract}
This paper presents the attitudes of high school students in Indonesia towards inter-ethnic and inter-religious socializing, courtship and marriage. It also explores how different personal characteristics and social conditions such as gender, ethnicity, type of school and community affect these attitudes. The basic findings come from a survey of more than 3,000 students in senior high schools in five provinces of Indonesia: Jakarta, Yogyakarta, West Sumatra, Central Kalimantan and Bali. Survey data were supplemented with data from interviews and focus group discussions with students and from participant observation in and around the same schools. The authors found that most students were positive about friendships with people of different ethnicities and different faiths. However, most students did not agree with inter-religious marriage, because they perceived that their religion forbad it. This research was part of a large team project examining how education can contribute to building a more tolerant and multicultural Indonesia.
\end{abstract}

Keywords: education; inter-ethnic and inter-religious relations; inter-religious marriage; Indonesia

Author details: Professor Lyn Parker (corresponding author) is with the School of Social and Cultural Studies at the University of Western Australia, 35 Stirling Highway, Crawley, Perth, WA 6009, Australia. E-mail: lyn.parker@uwa.edu.au. Dr Chang-Yau Hoon is an Assistant Professor in the School of Social Sciences at Singapore Management University and Adjunct Research Fellow at the University of Western Australia. E-mail: cyhoon@smu.edu.sg. Raihani is a Senior Lecturer in the Faculty of Islamic Education and Teacher Training at UIN Suska Riau in Indonesia and Adjunct Research Fellow at the University of Western Australia. E-mail: raihani@uwa.edu.au.

This paper presents findings about the attitudes of high school students in Indonesia towards inter-ethnic and inter-religious socializing, courtship and marriage. ${ }^{1}$ While Indonesia post-1998 is a much more open and democratic society than it was under President Suharto, there are still several factors hindering open and tolerant multiculturalism: there is a lack of tolerance of minority groups of various types (for example, some religious minorities, atheists and secularists, some ethnic minorities, people of alternative sexualities) and an 'absent state' [negara absen] when it comes to protecting minorities; there is continuing racism towards some minorities, such as the Chinese and Papuans; and religious fundamentalism

1 This article presents research conducted with funding from Australia Research Council Discovery Grant DP0984683, under the auspices of the Indonesian Ministry for Research and Technology and with approval from the UWA Ethics Office. The authors thank these institutions for their support and their research assistants for their professional and enthusiastic work. 
has emerged as an important force in Indonesian society. This study was triggered by the apparent increase in inter-religious intolerance and violence in Indonesia recently, as evidenced by an increasing number of attacks on minority places of worship (Crouch, 2009) and by recent strengthening of the religious and state authorities' regulation of inter-religious socializing and marriage (Seo, 2013). Our analysis is underpinned by the multiculturalist assumptions that mixing or socially interacting with Others is desirable for building a more multicultural Indonesia, and that educational institutions can play an important role in this process. In schools, encouraging interaction with Others can be done through formal means such as the curriculum, and informally, for instance, through promoting mixed student organizations such as the Red Cross. Schools do not always make this informal role explicit, though it is notable that some religious schools do emphasize a role in the opposite direction: they emphasize their religious exclusivity.

The basic findings presented come from a survey of more than 3,000 students in senior high schools in five provinces of Indonesia: Jakarta, Yogyakarta, West Sumatra, Central Kalimantan and Bali. The survey is part of a large team project that examines how education can contribute to building a more tolerant and multicultural Indonesia. The research team co-designed the survey and administered it in our different research sites. The schools surveyed were carefully chosen with regard to class, religion, ethnic make-up, private/public and vocational/general status. The survey data were supplemented with data from interviews, focus group discussions (FGDs) and participant observation, which were conducted in some of the same schools across Indonesia over the period 2009-2011. The chief value of the survey is that it shows patterns of attitudes; its chief weakness is that it does not adequately explain those patterns, though survey questions did ask students why they held particular attitudes. Hence, we use the qualitative data and the socio-cultural and historical context to explain the patterns revealed in the survey.

The paper begins with a brief discussion of the sensitivities of inter-religious socializing, the historical context of inter-religious marriage and different understandings and interpretations of the legality and acceptability of inter-religious marriage in Indonesia. Then we outline the survey and provide a profile of our student respondents. The main body of the article looks in turn at student attitudes towards inter-ethnic and inter-religious friendships, boyfriend/girlfriend relationships and marriage.

\section{The context}

Indonesian society has long been characterized as plural and diverse. Religious tolerance and pluralism were held to be unique features of Indonesian society. Intermarriage between people of different faiths has not been uncommon historically (Chee et al, 2009, p 3), and it is not uncommon to find different members of the same family adhering to different religions (for example, Beatty, 1999, 2002).

However, inter-religious socializing has been considered undesirable by some religious authorities due to the perceived threat of conversion - particularly the threat of Christianization (see Husein, 2005; Mujiburrahman, 2006). Various religious and state regulations to prevent inter-religious socializing have been issued during and since the New Order of Suharto (1966-98). For instance, in 1970 the Ministers of Religion and the Interior issued a joint ministerial decree saying that 
no religion was allowed to proselytize in a region where another religion already dominated (Bowen, 2003, p 236). In 1974, respected Islamic scholar Hamka issued a fatwa prohibiting Muslims from participating in Christmas rituals. In 1981, the Majelis Ulama Indonesia (MUI, Indonesia Ulama Council) issued a fatwa on the same issue, and the fatwa was reiterated in 1993 in a joint statement made by several Islamic leaders (see Bowen, 2003, pp 235-238). Mujiburrahman (2006) argues that the Muslim discourse on Christianization reflects the 'minority mentality' of Islamic groups in Indonesia during the Suharto era. Although obviously a numeric majority, Muslim groups and political parties were marginalized and weakened by the military regime: 'The logic of this discourse is that the state should protect the weak [Muslim groups] through certain regulations' (Mujiburrahman, 2006, p 103). Today, similar concerns are evident in the disapproval or prohibition of greetings such as wishing Christians a 'Happy Christmas' (Munjid, 2013), or in Muslim disapproval of Muslim students singing in Christian schools. In 2005, MUI decreed that praying together with non-Muslims was prohibited for Muslims; and also in 2005, it issued a fatwa opposing pluralism, liberalism and secularism (Gillespie, 2007).

Various factors have combined in such a way that the legitimacy of religious pluralism is now regularly challenged in public discourse in Indonesia: the Suharto regime's assimilationist version of the state motto of Bhinneka Tunggal Ika [Unity in Diversity]; MUI conservatism and an increasingly literal understanding of the Qur'an and selected Hadith; the existence of an impressively free press that has triggered a conservative media backlash; and the inaction of the current regime in protecting religious minorities. Religious pluralism is most clearly challenged by the perception that inter-religious marriage is a threat to religious harmony. Sociologically, intermarriage between different groups in society can be seen as an effective way to bring greater understanding between groups, for it has the potential to break down boundaries (Chee et al, 2009); it can also speak to gender equality between marriage partners (White and Anshor, 2008, p 146).

One of the most controversial laws that has affected inter-religious relations in Indonesia is Marriage Law No 1/1974. It states that marriage is religious in character, and specifically prohibits marriage outside the laws of the respective religions and beliefs (Elucidation, Article 2). However, the Marriage Law only recognizes marriages registered with the Civil Registration Office and not religious institutions. In 1980, MUI issued a fatwa against inter-religious marriages and forbad marriage between a Muslim man and a woman of the ahl al-kitab ['People of the Book': that is, Christians and Muslims], a marriage that is interpreted as being permitted in the Qur'an (5:5) by the dominant school of Islamic law in Indonesia, the Shafi'i madzhab (Feener, 2007; Chee et al, 2009; Cammack, 2009). Again, in 2005, MUI issued a fatwa against inter-religious marriage. A Supreme Court ruling in 1989, about a marriage between a Muslim bride and a Christian groom, indicated that the marriage could go ahead in the Civil Registration Office, but the rationale provided by the Court was that the bride, by marrying out of her faith, was an apostate (Butt, 1999, pp 136-137; Seo, 2013, p 82). This made interreligious marriages increasingly difficult from the 1990s as the Civil Registration Office refused to register such marriages.

Nahdlatul Ulama (NU), the largest Islamic organization in Indonesia, issued fatwa in 1962, 1968 and 1989, stating that inter-religious marriage was not permitted 
for Muslims (Seo, 2013, p 82). Muhammadiyah, the second largest Islamic organization, views marriage between a Muslim man and a non-Muslim woman as threatening because: (1) Muslim men have tended to convert to the religion of their non-Muslim wives, and (2) children of such marriages commonly adhere to the religion of their mother (Cholil, 2009, p 145). So it is not surprising that many Muslims in Indonesia go 'far beyond the standard religious law texts' (Bowen, 2003, p 235) in believing that their religion forbids a Muslim (of either gender) to marry someone of a different religion.

The key assumption behind these regulations is that inter-religious marriage will lead Muslims to convert to other religions (Cholil, 2009, p 140). Indeed, according to Seo (2013, p 93), conversion for the sake of marriage is the principal cause of conversion in Indonesia, and the Marriage Law is the single most important motivator of conversion. Nevertheless, in everyday reality, people exercise agency to circumvent these regulations. Certainly, some Muslims believe that a Muslim man may marry a non-Muslim woman, in accordance with the Qur'an. Others take a pragmatic approach to religious conversion, though there is sometimes then a question mark over the religiosity of those who convert for marriage. Seo argues that conversion for marriage should be seen as a process of flexible adaptation to the wider socio-political context, and emphasizes that converts do not usually suffer a radical disjuncture in their social lives as a result (Seo, 2013). Lukito observes that:

'The most common method of building agreement between the two aspirants to a marriage is for one of them to convert to the religion of the other before the contract is agreed. Thus when the contract is actually finalized, the marriage would not be an interfaith marriage, since the couple would share the same religious affiliation. After the contract, the person who converted would revert to his/her previous religion.' (2009, p 41)

It has also been noted that more affluent couples register their marriage overseas in countries such as Singapore where there are no such restrictions (Seo, 2013, p 76).

This is the socio-political context which provided the motivation for our study, and which also provides some explanation for the patterns that our study revealed.

\section{The survey}

The research team designed the survey and administered it in senior high schools. As noted above, the surveyed schools were carefully chosen; however, it was not always possible to control access to schools; nor was it always possible to select particular classes. Our sample was not intended to be and cannot be taken as 'typical' or representative of the student body of senior high schools in Indonesia.

We begin with a quick profile of our 3,114 survey respondents. Forty per cent of our participants were male and $60 \%$ female. The mean age of our respondents was 16 years. We collected surveys in five provinces: Jakarta, Yogyakarta, West Sumatra, Central Kalimantan and Bali (see Table 1). In Central Kalimantan, all the schools were in the capital city, Palangkaraya. In West Sumatra, all the schools were in towns and surrounding areas in the highlands. In Bali, the schools were carefully chosen to represent both rural and urban, and poor and high academic performance. 
Table 1. Survey sites.

\begin{tabular}{lcc}
\hline Province & $\begin{array}{c}\text { Number of } \\
\text { questionnaires }\end{array}$ & Percentag \\
Yogyakarta & 1,018 & 32.7 \\
Palangkaraya & 616 & 19.8 \\
Jakarta & 620 & 19.9 \\
West Sumatra & 311 & 10.0 \\
Bali & 549 & 17.6 \\
Total & 3,114 & 100.0 \\
\hline
\end{tabular}

Most senior high schools are in towns or cities, but they cater to students who are both rural and urban. Other studies involving surveys of senior high school students have shown that the majority of students are typically urban and living at home, but a significant minority are from villages as well as from other towns and cities, living away from home, either boarding with relatives or living in kost [boarding houses] (for example, see Nilan et al, 2011; Parker and Nilan, 2013). Students in senior high schools constitute a little over half of the relevant age group: 55\% of those aged 16-18 years are enrolled in senior high school (BPS, 2008, p 33). They represent the more economically comfortable half of the Indonesian population.

The religious affiliations of respondents in our survey sample do not reflect national percentages of religious affiliations. In this list, the first figures are the percentage of our sample, and the second figures, in brackets, are national percentages based on the 2010 Census: Islam 67.1\% (87.2\%); Protestant $13.8 \%$ (6.9\%); Hindu 13.5\% (1.7\%); Catholic 3.4\% (2.9\%); Buddhist 1.5\% (0.7\%); Confucian $0.1 \%(0.04 \%)$ (BPS, 2011). As indicated earlier, we were not aiming for a nationally representative sample because we were looking for particular types of schools that catered for particular groupings - especially religious and ethnic minorities. The minority-heavy sample may constitute a limitation of our study and could be revisited in future studies. However, our findings provide useful foundational information about inter-ethnic and inter-religious relations among students. Our qualitative data to some extent compensate for the limitations of the sample.

We collected information about ethnicity. Table 2 shows the distribution of the ethnic identity of the fathers of our respondents, for the 10 most frequent responses. Our sample bears no relation to the national distribution of ethnicities in Indonesia and is mainly a product of our choice of provinces and types of schools.

Table 2. Ethnic identity of fathers of respondents.

\begin{tabular}{lc}
\hline Ethnicity & Percentage \\
Javanese & 40.7 \\
Balinese & 14.0 \\
Minangkabau & 9.1 \\
Chinese & 7.3 \\
Dayak & 6.6 \\
Banjarese & 5.7 \\
Sundanese & 2.8 \\
Batak & 2.9 \\
Betawi & 2.6 \\
Malay & 1.7 \\
Total & 100.0 \\
\hline
\end{tabular}


As mentioned earlier, we are interested in how different types of schools foster religious and ethnic tolerance. The Indonesian system of schooling is quite complex in terms of types of school. At senior high school level, with students generally aged 16-18 years, the school system consists mainly of SMA (general senior secondary schools), SMK (vocational schools) and MA (Islamic day schools). There are many private schools in these three categories, and many private religious schools such as pesantren [Islamic boarding schools], Catholic and Protestant schools. We administered surveys in 31 schools. Table 3 presents the number of survey respondents in these different types of school.

Two main ministries administer and manage schools: the Ministry of Education and Culture and the Ministry of Religion. Under the Ministry of Education and Culture, there are SMA, SMK, other Islamic schools, Catholic schools and Protestant schools, whilst under the Ministry of Religion, there are MA and pesantren. It is interesting to see that, of all the possible religious schools, the Ministry of Religion only administers MA and pesantren; other religious schools are under the Ministry of Education and Culture. These latter schools characterize themselves as following the Ministry of Education and Culture curricula but with an Islamic, Catholic or Protestant environment and culture. On the other hand, MA and pesantren adopt both the Ministry of Education and Culture and Ministry of Religion curricula. The Ministry of Religion curricula contain mainly (Islamic) religious subjects. Table 4 shows the different types of schools in our five field sites.

As well as collecting basic biographical data, and the topics we canvass below, the survey asked students about their school subjects and curricula. In this paper, we focus on three groups of questions about inter-ethnic and inter-religious

Table 3. Number of respondents in the different types of schools.

\begin{tabular}{lcr}
\hline Schools & Number & Percentage \\
SMA & 1,306 & 41.9 \\
SMK & 544 & 17.5 \\
MA & 364 & 11.7 \\
Other Islamic schools & 254 & 8.2 \\
Pesantren & 205 & 6.6 \\
Catholic schools & 239 & 7.7 \\
Protestant schools & 202 & 6.5 \\
Total & 3,114 & 100.0 \\
\hline
\end{tabular}

Table 4. Cross-tabulation of types of school by field sites.

\begin{tabular}{|c|c|c|c|c|c|c|c|}
\hline Type of school & $\begin{array}{l}\text { State or } \\
\text { private }\end{array}$ & Yogyakarta & Palangkaraya & Jakarta & $\begin{array}{c}\text { West } \\
\text { Sumatra }\end{array}$ & Bali & Total \\
\hline SMA & State & 1 & 1 & 4 & 2 & 4 & 12 \\
\hline SMK & State & 1 & & 1 & 1 & 2 & 5 \\
\hline MA & State & 1 & 1 & 0 & 0 & & 2 \\
\hline $\begin{array}{l}\text { Other Islamic } \\
\text { schools }\end{array}$ & Private & 1 & 1 & 0 & 0 & 1 & 3 \\
\hline Pesantren & Private & 1 & 0 & 0 & 1 & 0 & 2 \\
\hline Catholic schools & Private & 1 & 1 & 0 & 1 & 0 & 3 \\
\hline Protestant schools & Private & 0 & 0 & 4 & 0 & 0 & 4 \\
\hline Total & & 6 & 4 & 9 & 5 & 7 & 31 \\
\hline
\end{tabular}


friendships, boy/girlfriend relationships and marriage. We asked about their experience and social practice as well as attitudes.

\section{Socializing and friendships}

Our survey results show that $73 \%$ of our respondents have a friend of another religion (Table 5). While this figure seems high, the word 'friend' does not necessarily mean the same thing in Indonesia as it does in the West. In Indonesia, the word for 'friends' often implies peers or fellows, rather than persons for whom one has a specific, personal liking. Therefore, if students were aware that some of their classmates were from a different religion, they might answer 'yes'.

We therefore wanted to explore a bit further, so we asked students if they and their friends of a different religion visited one another (Table 6). Nearly $80 \%$ of respondents who had friends of another religion indeed visited those friends. This indicates that the 'friendships' were not limited to a mere knowledge of the presence of religious Others in the class, but that they were quite close relationships, though we do not know precisely how close. We asked those students who had a friend of a different religion but did not visit one another, why they did not visit each other. The overwhelming responses were simply the pragmatic ones: that they lived too far away (261 responses) or that there had been no opportunity to visit that friend (203 responses). Only 10 students reported that 'religion does not allow it'.

Next we consider some of the possible ways to break down these statistics, looking at individual characteristics. First, by gender: we see that there is not much difference between boys and girls: $75 \%$ of boys and $72 \%$ of girls have friends of different religions. Second, Table 7 shows the breakdown by religion, apparently showing that more students of minority religions have friends of other religions than do Muslim students. However, in interpreting these results one has to consider the different environments in which our respondents live. Some live in very mixed places where neighbours are of all different religions, and some go to mixed-religion schools where their classmates are of all different religions. But

Table 5. Do you have a friend of another religion?

\begin{tabular}{lcc}
\hline & Frequency & Percentage \\
Yes & 2,269 & 73 \\
No & 840 & 27 \\
Total & 3,109 & 100 \\
\hline
\end{tabular}

Table 6. Do you visit that friend of another religion?

\begin{tabular}{lcc}
\hline & Frequency & Percentage \\
Yes & 1,790 & 78.6 \\
No & 487 & 21.4 \\
Total & $2,277^{a}$ & 100 \\
\hline
\end{tabular}

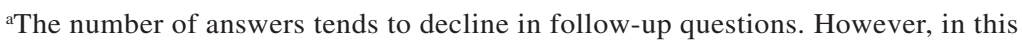
table we expected to receive 2,269 answers and in fact received slightly more $(2,277)$, due, no doubt, to students thinking they had to answer regardless of their not having a friend of another religion. 
Table 7. Cross-tabulation of respondents' religion by friend of other religion.

\begin{tabular}{lccc}
\hline Respondent's religion & & Friend of other religion? \\
& Yes $(\%)$ & No $(\%)$ & Total $(n)$ \\
Islam & 67.0 & 33.0 & $100(2,085)$ \\
Protestantism & 91.4 & 8.6 & $100(431)$ \\
Catholicism & 98.1 & 1.9 & $100(106)$ \\
Hinduism & 74.0 & 26.0 & $100(420)$ \\
Buddhism & 97.8 & 2.2 & $100(46)$ \\
Confucianism & 100.0 & 0 & $100(3)$ \\
No stated religion & 100.0 & 0 & $100(2)$ \\
Total & 72.9 & 27.1 & $100(3,093)$ \\
\hline
\end{tabular}

many others have no exposure to young people of a different religion, so the chances of having a friend of another religion are quite slim. These figures, therefore, are not to be taken to mean that one religion is more 'friendly' per se than another.

Similarly, the findings according to region of field site (Table 8) are more revealing of opportunities to mix with religious Others than they are of openness or friendliness per se. The table shows that students in West Sumatra tend not to mix with students of other religions. West Sumatra is quite a homogeneous province: the vast majority of people there are Minangkabau Muslims. In highland West Sumatra, the population is more homogeneous than in the capital city, Padang, and the survey schools were all in this highland heartland of the Minangkabau, so it is not surprising that over $40 \%$ of young people in our survey do not have friends of another religion. Often, too, there are differences within a province, and one can pick out particular schools and predict the likelihood of inter-religious friendships. For example, one of the schools in Bali was a state high school in a remote, very rural area, and all the students in that school were Hindu and all had only Hindu friends. In contrast, state high schools in the capital city of Bali, Denpasar, are quite mixed religiously because the population of Denpasar is now quite heterogeneous, so there is more religious mixing in those schools. In Palangkaraya, most of the students are exposed to different religions because of the diverse community in which they live, but state SMA students mix more than students at MA and other religious schools.

Qualitative data from interviews, FGDs and participant observation add to our understanding of religio-ethnic mixing. Ayu, for instance, was a young Minangkabau woman who attended a state senior high school in a highland town in West Sumatra (Interview, West Sumatra, 22 January 2011).

Table 8. Cross-tabulation of region of field site by friend of other religion.

\begin{tabular}{lccc}
\hline Region & & Friend of other religion? & Total \% $(n)$ \\
& Yes $(\%)$ & No $(\%)$ & $100(1,016)$ \\
Yogyakarta & 65.8 & 34.2 & $100(616)$ \\
Palangkaraya & 80.0 & 20.0 & $100(620)$ \\
Jakarta & 83.1 & 16.9 & $100(310)$ \\
West Sumatra & 57.7 & 42.3 & $100(547)$ \\
Bali & 75.5 & 24.5 & $100(3,109)$ \\
Total & $73.0(2,269)$ & $27.0(840)$ & 100 \\
\hline
\end{tabular}


Since her school had made the jilbab a compulsory item of the school uniform, there were almost no non-Muslim female students in her school. She and her family were recent arrivals (self-described as pendatang [newcomers], though from the Minang heartland) in a busy, crowded area of town dominated by the market and bus terminus. Her immediate family was Muslim; when asked if anyone in her larger family was a non-Muslim, she answered 'Alhamdulillah dari keluarga besar gak ada' [Thankfully, there are no non-Muslims in my extended family]. She was expressing a preference for a mono-religious family community over diversity. Also, although she is a member of the dominant ethnic group and religion, she felt the need to conform to the norms of the locals in her suburb:

Interviewer: 'So as a newcomer [pendatang] how do you get on with the locals there?'

Ayu: 'Yeah, our relationships are just the usual, so they accept newcomers, provided the newcomers observe their norms. It's like, so, yeah, we value each other.'

This sense of the need to assimilate pervaded the discourse of locals and immigrants in all research sites. Respondents always quoted the aphorism, 'di mana bumi dipijak disitu langit dijunjung' [wherever we stand is where we honour the sky], which in essence means that one should respect the local/host culture and norms. However, the extent to which the immigrant should melt into the host culture is not clear. At the same time, there is a strong sense that Other people have a right to their distinctive culture and religion.

Ayu did have one close non-Muslim friend - from a Protestant military family that had been posted to this town and lived in the army barracks nearby. The two girls had been friends in primary school and maintained their relationship, even though they subsequently went to different schools. The case of Ayu's friend suggests that some aspects of the nation-state - notably, the mixing of the population that occurs through the posting of military personnel and public servants all around the country - can have an integrative and positive multicultural effect. ${ }^{2}$ On the other hand, that state school's decision to make the jilbab compulsory school uniform [jilbabisasi] for all girls, regardless of their religion, had the opposite effect: it was now very uncomfortable for non-Muslim girls to attend the local state school. In the SMK in Yogyakarta, jilbabisasi was applied exclusively to Muslim girls. This policy did not seem to have had an impact on non-Muslim attendance at the state school, but it did influence the identification of students by religion. For example, Muhdi, a teacher of Islam, said: 'If you see a girl not wearing a jilbab here, you can be sure that she is a non-Muslim' (Interview, Yogyakarta, 18 March 2010). From our observation, there was positive inter-religious mixing in the SMK in Yogya and in state schools in Palangkaraya.

The type of school students attend (Table 9) is a better predictor of social mixing than region or individual religious identity. Attending a pesantren means that one is very likely not to have a friend of another religion: nearly three-quarters of students at pesantren did not have a friend of another religion. Attending a madrasah

However, in Papua, that same policy of posting non-local civil servants and military personnel is often interpreted by locals as a colonizing move that marginalizes them in their own land. 
Table 9. Cross-tabulation of type of school by friend of other religion.

\begin{tabular}{lccc}
\hline Type of school & \multicolumn{3}{c}{ Friend of other religion? } \\
& & No $(\%)$ & Total $(n)$ \\
SMA & 82.9 & 17.1 & $100(1,304)$ \\
SMK & 68.8 & 31.3 & $100(544)$ \\
MA & 53.6 & 46.4 & $100(364)$ \\
Other Islamic school & 64.4 & 35.6 & $100(253)$ \\
Pesantren & 26.1 & 73.9 & $100(203)$ \\
Catholic school & 95.4 & 4.6 & $100(239)$ \\
Protestant school & 86.6 & 13.4 & $100(202)$ \\
Total & 73.0 & 27.0 & $100(3,109)$ \\
& $(n=2,269)$ & $(n=840)$ & \\
\hline
\end{tabular}

[Islamic day school] also seems to militate against having a friend of another religion (though the fact of living in a neighbourhood rather than in a boarding school probably helps). The apparent openness of students in Protestant and Catholic schools was quite surprising. This may be attributable to the fact that many of these schools have a strong academic reputation and are open to and attract students of different religions because they are the top schools in the area. Therefore, unlike most Muslim schools, the student body is often religiously mixed, which enables students' inter-religious socializing. One can also distinguish between Protestant and Catholic schools to some extent: Catholic schools tend to attract more Muslim students than Protestant schools. There may be several reasons for this - for instance, the Protestant school curricula are more confessional and evangelical than the Catholic curricula, and some cater exclusively to the Protestant Chinese community.

There is a Catholic school in highland West Sumatra that enjoys the reputation of being the best school in town. It has been there since colonial times, and has an extraordinary history. The present principal is a Catholic woman, but the former principal was a Muslim. In an earlier era, the head of a famous pesantren nearby sent his daughter to this Catholic school. Although Catholic, the school accepts Muslim students and students of other faiths. It has long offered education from kindergarten to junior high school, but is now expanding to senior high school. When Parker visited in 2011, it had only the first grade of senior high: a cohort of 53 students, of whom 32 were Muslim (60\%), 13 were Catholic, seven Protestant and one Buddhist. The religious affiliation of the teachers was even more in favour of Muslims: 16 of the 24 teachers (67\%) were Muslim, five were Catholic, two were Protestant and one Buddhist. In such a school, it would be extraordinary if students did not have friends of other faiths.

Thus, while none of these factors (gender, region/community, type of school, religious identity) definitively fosters or prohibits inter-religious friendship, our data do indicate that certain conditions make it more likely for students to mix inter-religiously. Gender does not seem to make much difference; community diversity and a mixed student body at school definitely provide opportunities for inter-religious mixing that young people adopt.

We also asked students if they had friends of a different ethnicity. Interestingly, even more respondents $(84.8 \%)$ have a friend of a different ethnicity than have a friend of a different religion (Table 10).

For this category of inter-ethnic friendships, we found that 2,197 (or $84.3 \%$ ) of 


\begin{tabular}{lcc}
\hline Table 10. Do you have a friend of another ethnicity? \\
\hline & Frequency & Percentage \\
Yes & 2,607 & 84.8 \\
No & 469 & 15.2 \\
Total & 3,076 & 100 \\
\hline
\end{tabular}

the 2,607 students with friends of another ethnicity visited those friends. We consider these results quite encouraging for the future of inter-religious and inter-ethnic relations in Indonesia, especially when we consider the MUI fatwa that discourage inter-religious social relations.

Looking more broadly at multicultural socializing in Indonesia, we asked about participating in religious celebrations of people of different religions. As noted above, this is a topic that has long been controversial in Indonesia. We found that almost two-thirds of our respondents would attend the religious celebration of another religion if they were invited. In the multicultural city of Palangkaraya, students of different religions routinely exchanged visits during the religious celebrations of other religions. During the Idul Fitri season, for example, non-Muslim students visited their Muslim friends. Likewise, Muslim students did not hesitate to visit their Christian friends at Christmas time. A Hindu vice-principal of a state SMA in Palangkaraya explained that at Galungan, a Hindu festival, he regularly spends millions of rupiah to prepare or buy food in anticipation of visiting colleagues and students of other religions.

\section{Berpacaran - having boyfriends and girlfriends}

In the context of Indonesia, it must first be noted that having a pacar [boy/girlfriend] is not the same as in the West, especially among the younger high school cohort (Parker and Nilan, 2013, pp 117-124). It usually does not extend to going out 'on a date' as a couple: it often consists of nothing more than exchanging passport photos and texting. It is rare for boyfriends or girlfriends of high school age to be invited home to meet the parents, and it is often kept a secret from them. There is little opportunity for the two to be alone, so the socializing is usually done in public, within a group.

We asked students if they had ever had a pacar, and $72.5 \%$ (2,238 respondents) said they had. We asked those who had not yet had a pacar why they had not. The most common answer was that they were 'too young'; then came 'because my parents forbid it', followed by 'because religion forbids it'. Many Muslim students take seriously the proscription of approaching fornication [zina], such as verse 34 of the Sura Isra [The Night Journey] in the Qur'an: 'And approach not fornication; surely it is an indecency and evil as a way'. They interpret this verse to indicate that adolescents may not date; nor may they be alone with a pacar.

Then we asked whether students had ever had a pacar of another religion, and of 2,346 answers, nearly one-third (755 respondents) replied in the affirmative. (It must be noted that there were 768 missing answers to this question.) We found this frequency of inter-religious courting quite surprising. When we asked whether students would have a pacar of another religion, the positive numbers went down: 
452 (23\% of 1,944 answers) said they would, 1,492 (77\%) said they would not; again, there were a lot of missing answers. The dominant reason students gave for why they would not have a pacar of another religion was indeed that the religions were different (936 of 1,324 valid answers: $71 \%$ ) - so for them religious difference was definitive; some students said it was because their parents would not agree (290/1,324: $22 \%)$ and some said it was because they did not want a pacar (98/1,324: $7.4 \%)$. We conjecture that the large number of missing answers in this category is due to the controversial nature of courting, let alone inter-religious courting.

At a Protestant school in Jakarta, a Catholic student told the researcher that her parents would not allow her to have a pacar who had a different religion. 'From the beginning my mum has already made that clear. What makes me frustrated is that our religion teaches us not to differentiate people [jangan beda-bedain] so why does my mum not allow me to go out with people whose religion is different?' (FGD, 23 July 2010). She revealed that her mother would not even allow her to date a Protestant, 'because Mum thinks that a relationship will lead to marriage, so why waste time on [a relationship with someone of a different religion]'. Her mother makes two assumptions: that dating will lead to marriage, and that marriage to someone of a different religion is out of the question. In another FGD at the same Protestant school, when students were asked whether they would consider dating someone from another ethnicity or religion, a female Protestant student said that different ethnicity was fine, but not different religion. 'Say if I date a non-Christian guy, I could be influenced by him. It may turn out that I will be attracted to his religion - it's kind of scary. On top of that, my parents don't allow me to date someone of a different religion.' (FGD, 30 July 2010)

In Palangkaraya, many students did not hesitate to have a pacar from another religion, though most of them would not go as far as marriage. In FGDs some students joked that having pacar of other religions could enrich one's experience. Rita, a Protestant student in an Islamic school in Palangkaraya revealed,

'I have had a Muslim boyfriend before. He was pretty cool. We didn't have any problem [related to our different religions]. We even always reminded each other [to carry out our devotional activities]. For instance, on Sundays, he would ask whether I had gone to church. Likewise, I'd ask whether he had performed his prayers.' (Interview, 20 April 2010)

As with friendships, pacar relationships between people of different ethnicities were not so rare: $40 \%$ of respondents had had a boy/girlfriend of another ethnicity (compared with one-third who had had a pacar of a different religion) (see Table 11).

When asked whether they would have a girl/boyfriend of another ethnicity, 1,275 of a total $1,774(72 \%)$ said they would, and 499 (28\%) said they would not. So we think that there is considerable open-mindedness among young people about having boyfriend and girlfriend relationships with people of both different religions and different ethnicities. The usual pattern prevails: that different ethnicity is less of a problem than different religion.

A male Chinese student at a Protestant school told the researcher that he had had an inter-ethnic relationship and it was not a problem. In his own words, 'My 


\begin{tabular}{lcc}
\hline \multicolumn{2}{c}{ Table 11. Have you ever had a boyfriend or girlfriend of another ethnicity? } \\
\hline & Frequency & Percentage \\
Yes & 1,130 & 39.9 \\
No & 1,702 & 60.1 \\
Total & 2,832 & 100 \\
\hline
\end{tabular}

family didn't know. You know, it was just for fun [buat happy-happy saja].' To him, a girlfriend of a different ethnicity was not a problem 'as long as we have the same religion [yang penting seiman]' (FGD, 28 August 2010). Another Chinese student who came from a strict Protestant family told the researcher that his parents were strictly against inter-ethnic and inter-faith relationships:

'Mum advised me that every human being is created to be in a matching pair. So the partner that one finds should be of the same religion. With regard to ethnicity, look for one of the same ethnicity, because different ethnicity means different culture and this will lead to conflict.' (Interview, 28 July 2010)

\section{Marriage}

We come now to the 'crunch question' of inter-religious marriage. In contrast to the questions about friendship and boy/girlfriend relationships, we could ask only about attitudes towards marriage. None of our respondents had personal experience of marriage, though of course some would have had mixed families. In our survey, we asked: What is your opinion about marrying people of a different religion? Students were asked to mark their attitudinal preference on a Likert scale (Table 12).

The combined 'disagree' and 'strongly disagree' opinions $(1,579)$ constitute $52 \%$ of total answers, so we can say that the generally positive attitude towards inter-religious friendships, and even inter-religious pacar relationships (remembering that one-third of respondents had had a pacar of a different religion), does not extend to marriage. Some respondents were explicit about this: 'For me, having a relationship with someone of a different religion stops at friend/pacar; it doesn't extend to marriage'.

We asked students about the reasons for their opinions on mixed marriages. The dominant response among the $52 \%$ who disagreed with inter-religious marriage was the definitive one that religion forbids inter-religious marriage. Others gave stronger reasons, such as that marriage to a non-Muslim would be tantamount to committing zina (having sex outside marriage, a major sin): 'My religion strongly forbids marrying someone with a different religion - they would be considered to have committed zina within the household'; or the more pointed, 'It's the same as zina in Islamic law'.

Table 12. Attitudes towards inter-religious marriage.

\begin{tabular}{cccccc}
\hline Strongly agree & Agree & Neutral & Disagree & Strongly disagree & $\begin{array}{c}\text { Total } \\
\text { (n) }\end{array}$ \\
0.5 & 6.05 & 41.5 & 38.5 & 13.4 & 3,042 \\
\hline
\end{tabular}


Many students responded that if two people were of different religions and wanted to marry, then one of them must convert to the other's religion:

'Islam teaches that we may not marry someone of a different religion. Before they get married, that person must convert to Islam [masuk agama Islam].'

'If someone is considering doing that ... it doesn't matter provided they do not apostatize from Islam. If they can, a member of the couple ... should convert to Islam.'

'...because we must marry within religion or a man/woman must be willing to change religions...'

Some students went on to express the common belief that people who change religion in order to get married are less than sincere. Others who disagreed with inter-religious marriage suggested that a marriage of two people of different religions would be vulnerable. For example:

'Because most [mixed marriages] would probably end in divorce because their conviction would be different and I feel they would be less than devout and strong.'

We were a little surprised that more students did not discuss the issue of the religious education of children in mixed marriages. Adults such as teachers quite often raised this as a problem, but only a few students mentioned it explicitly:

'[A mixed marriage] would make it difficult for children because each side would try to promote their own religion to the children.'

In the Catholic school in Palangkaraya, one student, Arman, whose father is Muslim and mother is Protestant, follows his father's religion. As many respondents told the researcher, there is a convention in Central Kalimantan that a man has higher status than a woman in an inter-religious marriage. The wedding is held in the groom's church or mosque, and the children of the marriage follow the father's religion. Arman was aware of this convention, but was not convinced that he was a good Muslim because he did not see a model of Muslim-ness from his mother, and his father was always busy and rarely at home. He said: 'I am a Muslim and want to be a good Muslim, but how? My mother is not Muslim, and I am now at a Catholic school which teaches only Catholicism.' (FGD, 24 May 2010)

The $42 \%$ of students who said they were 'neutral' about inter-religious marriage may have meant that they did not have a strong opinion one way or the other. This could be tantamount to saying that they would tolerate it, in which case we could allocate them to the 'agree' camp. There were many like this: they would say they were 'neutral' about mixed marriage because 'it is their right', or because 'love cannot be divided by religion'.

However, many of those who said they were neutral about inter-religious marriage did not seem to be when we look at the reasons for their opinions: many qualified their neutrality with a condition, such as, "provided that they really re- 
spect or love each other'. Some even said they were neutral or agreed with interreligious marriage provided one partner changed their religion! Those who were neutral towards, and the small minority of less than $7 \%$ who agreed with, interreligious marriage usually advanced one of three main reasons for their opinion: the primacy of love (usually cinta, sometimes kasih saying) - love conquers difference; the right $[h a k]$ to marry whoever one wants; or the idea that one's life partner or soulmate [jodoh] is in the hands of God. The last reason could theoretically be advanced in support of inter-religious marriage, assuming an open-minded God, or in opposition to inter-religious marriage - why would the God of one religion give one a soulmate who was of another religion? However, we found that only a handful of students paired jodoh with opposition to inter-religious marriage, and then it was quite a fatalistic attitude: for example, '[Marriage] should be within religion, but if indeed it is with a soulmate [of a different religion], what more can be said?' This sets up an intriguing opposition between religion and fate. The vast majority who talked of jodoh saw the choice of soulmate as being determined by God, and advanced this as a reason for being neutral about interreligious marriage. Some examples of these three main reasons for their tolerance or support of inter-religious marriage are:

\section{Discourse of love:}

'Love cannot be restricted by anything.'

'Love does not see [memandang] religion.'

'Love and affection cannot be separated by religion.'

'Because God created love so that people who are different can become one religion and ethnicity and race should not "box" humankind.'

2. Discourse of rights [hak]:

'Because each person has their own right to choose their own partner...'

'Because each person has the right to their own opinion about their individual religion; with each valuing one another, a way of life with different religions [kehidupan beda agama] can be undertaken.'

'Marriage is the uniting of two different individuals, so if the difference is religion it needn't be a problem, provided both sides have already thought about the consequences.'

'Religion is the right of each person; love is also the right of each person; a difference in religion is not an obstacle/prohibition [penghalang] because each person has the right to choose the religion they want and the right to choose the partner they want.'

\section{Discourse of soulmates [jodoh]:}

'Indonesia is a multicultural country that consists of many different types of belief; moreover jodoh is in the hands of God.'

'Because I am certain that jodoh is in God's hands and will not always be of one religion; what is important is that they understand each other.'

This and the following response seem to say that God is not necessarily opposed to inter-religious marriage: 
'Because God decides our soulmate, it's not certain that they will be the same religion as us.'

The discourse of jodoh was often couched in deterministic or fatalistic language: for example, 'If one's partner is already chosen, it can't be refused'.

We turn now to the gendered patterns of opinions about inter-religious marriage. Table 13 sets out our findings, simplifying the earlier five categories of opinions (strongly agree, agree, neutral, disagree and strongly disagree) to three (agree, neutral and disagree).

Generally speaking, females are more disapproving of inter-religious marriage than males: $57 \%$ of females disagree with inter-religious marriage compared with $43.7 \%$ of males. This is perhaps not surprising. First, there is the oft-observed greater religiosity of females than males (for example, Stark, 2002; though see also Loewenthal et al, 2002), so if girls believe that their religion forbids inter-religious marriage, they are perhaps more likely than boys to obey this dictum. Second, as noted above, the Qur'an seems to permit the marriage of a Muslim man and a woman of the ahl al-kitab [People of the Book], such as a Christian woman (Bowen, 2003, p 235). Although inter-religious marriage has been controversial for three decades, the general trend has been towards a hardening of boundaries and increasing policing of inter-religious marriage (Bowen, 2003, pp 235-252), such that it is now very difficult indeed for inter-religious marriages to go ahead. It seems that the MUI fatwa and the response to it mean that women no longer have the option of a mixed marriage: a non-Muslim woman cannot take a Muslim husband, as she could formerly, and a Muslim woman must take a Muslim husband. Third, it may well be that young women are more beholden to their parents and communities when it comes to choice of marriage partner than young men.

Next we look at attitudes towards inter-religious marriage according to the religion of respondents, as shown in Table 14.

Interestingly, this table shows that Muslims and Protestants have similar attitudes towards inter-religious marriage: they form a block of opposition to inter-religious marriage, and only $4 \%$ of Muslim and Protestant students agree

Table 13. Attitudes towards inter-religious marriage by gender.

\begin{tabular}{lcccc}
\hline & Agree (\%) & Neutral (\%) & Disagree (\%) & Total \% (n) \\
Males & 9.3 & 47.1 & 43.7 & $100.1(1,207)$ \\
Females & 4.8 & 37.9 & 57.3 & $100.0(1,835)$ \\
All & 6.6 & 41.5 & 51.9 & $100.0(3,042)$ \\
\hline
\end{tabular}

Table 14. Attitudes towards inter-religious marriage by religion of respondent.

\begin{tabular}{|c|c|c|c|c|}
\hline & Agree (\%) & Neutral (\%) & Disagree (\%) & Total \% (n) \\
\hline Islam & 4.3 & 34.3 & 61.4 & $100.0(2,055)$ \\
\hline Protestant & 4.2 & 37.4 & 58.4 & $100.0(425)$ \\
\hline Catholic & 19.2 & 57.7 & 23.1 & $100.0(104)$ \\
\hline Hindu & 15.1 & 75.2 & 9.7 & $100.0(404)$ \\
\hline Buddhist & 19.6 & 69.6 & 10.9 & $100.1(46)$ \\
\hline Confucian & 33.3 & 66.7 & 0 & $100.0(3)$ \\
\hline All & 6.5 & 41.5 & 52.0 & $100.0(3,037)$ \\
\hline
\end{tabular}


with mixed marriage. Catholics, Hindus and others are more relaxed about the issue.

In a Protestant school in Jakarta, the researcher observed that besides parental disapproval of inter-religious marriage, teachers were also against it. It is likely that teachers convey their disapproval to the students. Most teachers were agreeable to inter-ethnic marriage, although some of them cited potential problems related to adat [custom]. But all teachers in that school, who were either Protestant or Catholic, were against inter-religious marriage. Some cited clashes in religious authority: for example, 'one ship cannot have two captains'. Others alluded to the problem of the education of the children of mixed marriages. For example, a sociology teacher argued, '[t]he problem is with the children in the future. It will be difficult to impart family values to them. Which principles should the parents use?' (Interview, 20 July 2010) Another teacher, who teaches character building, gave the example of the boyfriend of her younger sister who came from a mixed marriage family:

'I feel sorry for my sister's boyfriend because he was confused when growing up. His father wanted him to carry out the Muslim prayers [sholat] while his mother took him to church on Sundays. Cases like this make me conclude that mixed marriages will only bring confusion - if not to the couple, then to their children.' (Interview, 20 July 2010)

Next we examine attitudes towards inter-religious marriage according to type of school. The responses are summarized in Table 15.

Students from pesantren seem to be the most opposed to inter-religious marriage, with students from madrasah coming second. It is useful to remember that many of the Catholic and Protestant schools are considered high-quality educational establishments and are open to students of other religions, so their student bodies are likely to be more mixed than those of Islamic schools. There is also the difference between Catholic and Protestant schools noted above, that Catholic schools seem more tolerant of religious difference, both in their curricula and in the attitudes of students. If we were considering the ideal composition of a student body that would best lend itself to live-and-let-live attitudes towards religious difference, the mixed religious composition of Catholic schools should be a salutary lesson.

The question of inter-ethnic marriage is not nearly as sensitive as the issue of

Table 15. Attitudes towards inter-religious marriage by type of school.

\begin{tabular}{lcccc}
\hline & Agree (\%) & Neutral (\%) & Disagree (\%) & Total \% (n) \\
SMAN & 6.7 & 41.1 & 52.2 & $100.0(1,277)$ \\
SMKN & 6.7 & 55.1 & 38.2 & $100.0(534)$ \\
MAN & 2.0 & 29.6 & 68.5 & $100.1(355)$ \\
Other Islamic school & 6.0 & 38.6 & 55.4 & $100.0(249)$ \\
Pesantren & 2.0 & 24.3 & 73.8 & $100.1(202)$ \\
Catholic school & 14.7 & 49.6 & 35.7 & $100.0(238)$ \\
Protestant school & 9.0 & 41.7 & 49.2 & $99.9(199)$ \\
Total & 6.5 & 41.6 & 51.9 & $100.0(3,054)$ \\
\hline
\end{tabular}


Table 16. Attitudes towards inter-ethnic marriage.

\begin{tabular}{cccccc}
\hline $\begin{array}{c}\text { Strongly agree } \\
\%\end{array}$ & $\begin{array}{c}\text { Agree } \\
\%\end{array}$ & $\begin{array}{c}\text { Neutral } \\
\%\end{array}$ & $\begin{array}{c}\text { Disagree } \\
\%\end{array}$ & $\begin{array}{c}\text { Strongly disagree } \\
\%\end{array}$ & $\begin{array}{c}\text { Total } \\
\%(\mathbf{n})\end{array}$ \\
6.2 & 26.5 & 64.0 & 2.9 & 0.4 & $100.0(3,057)$ \\
\hline
\end{tabular}

inter-religious marriage, as Table 16 shows. Nearly two-thirds of respondents felt neutral about marriages of mixed ethnicity, and only $3 \%$ disagreed with them.

The figures for attitudes towards inter-ethnic marriage by ethnicity show that the greatest opposition to mixed-ethnicity marriage was in Bali, where $9 \%$ of students disagreed with it. Balinese identity is inextricably bound up with Balinese Hinduism, and it is not uncommon for Balinese who convert to another religion (usually through marriage) to be 'thrown away' by their community and to lose their ethno-ancestral identity (Bakker, 1997; Picard, 2011). The percentages for disagreement with inter-religious marriage and inter-ethnic marriage for students from Bali are almost identical.

A Chinese Protestant student said, 'I think to have an inter-ethnic relationship can be a little troublesome [ribet]. For example, I'm a Chinese and my parents are from Kalimantan. If I marry a Batak, our adat will be different, and we may experience some difficulty in our relationship. It may be difficult to complement our adat.' (FGD, 30 July 2010) At one of the Protestant schools, one of the very few Muslim students opined, 'I agree with inter-ethnic marriage because according to me, it is a good thing for one ethnic group to get to know another ethnic group. As for inter-religious marriage, I have no problem with it. Religion is an important guide [pegangan] for an individual but that is their own business with God. Hence, there should not be any compulsion.' (Interview, 28 July 2010)

\section{Conclusion}

Our paper is built on the assumption that mixing or socially interacting with others is desirable for building a more tolerant and multicultural Indonesia. This assumption is based on the understanding that through getting to know people who are different, young people will not fear the Other, and they will appreciate that people of another religion or ethnicity are human beings with needs and desires, families and friends, ambitions and dreams, just like they are. It is hoped that through the building of normal social relations with the Other, young people will be able to appreciate that people of different religion and ethnicity can be moral as well as immoral, can act towards the common good, have worth, and should be respected as human beings with the same rights as oneself. However, we also acknowledge that social interaction with the Other does not guarantee these socially desirable attributes; we have seen throughout the twentieth century, within Indonesia as in many other countries, that heterogeneous communities that have lived in peaceful coexistence for generations can erupt in serious and violent conflict.

We find that young people generally in Indonesia are not only positive about but also practise inter-ethnic and inter-religious socializing in their everyday lives. Nearly three-quarters of our sample have friends of another religion and visit them in their homes, and an even higher percentage have friends of a different 
ethnicity. Most young people would attend the religious celebration of another religion if they were invited. This paper has also explored how different personal identities, backgrounds and conditions facilitate such mixing. We found that community diversity and a mixed student body at school definitely provide opportunities for inter-religious friendship that young people take up. Catholic schools in particular seem to foster openness to religious Others.

We want to point out that while many young people are positive about 'difference' and do indeed have friends of other religions and ethnicities, there is still a feeling that assimilation into the dominant culture is necessary. We also have to bear in mind the strength of stereotypes about religions and ethnicities. We found that many people can think of a string of uncomplimentary adjectives that describe other religions and ethnicities (such as arrogant, extreme, miserly, terrorist, materialist), such that even if they know and love someone of another religion and ethnicity, that person's fine qualities are seen as the exception that proves the rule (Hoon, 2008, pp 125-145).

Insofar as young people in Indonesia approve of boy/girlfriend relationships, they are also positive about inter-religious and inter-ethnic courtship. We were surprised that nearly one-third of respondents who answered the relevant survey question had had a boy/girlfriend of another religion. However, when we asked students who had not had a pacar of a different religion if they would consider it, $77 \%$ said they would not, and the main reason given was indeed religious difference.

It is inter-religious marriage that is the real 'crunch question' in Indonesia, and on this issue we found students much less easy-going. Most students disagree or disagree strongly with inter-religious marriage. There is variation according to provinces: students in Bali showed the lowest degree of opposition, and students in Yogyakarta were also more tolerant. As with inter-religious friendships and boyfriend/girlfriend relationships, students in Catholic schools were the most tolerant of inter-religious marriage. Most Muslim and Protestant students disagree or disagree strongly with inter-religious marriage. Another pattern we found was gender difference: opposition to inter-religious marriage is stronger among girls than boys.

Young people who have friends, boy/girlfriends, and even potential marriage partners of another ethnicity or religion are not proof against inter-ethnic or interreligious conflict and violence. Nevertheless, actually knowing and appreciating the human qualities of a person of another ethnicity and religion, generally speaking, must be an aid to the development of not only sympathy but also empathy for the Other.

\section{References}

Bakker, F.L. (1997), 'Balinese Hinduism and the Indonesian state: recent developments', Bijdragen tot de Taal-, Land-en Volkenkunde, Vol 153, No 1, pp 15-41.

Beatty, A. (1999), Varieties of Javanese Religion: An Anthropological Account, Cambridge University Press, Cambridge.

Beatty, A. (2002), 'Changing places: relatives and relativism in Java', Journal of the Royal Anthropological Institute, Vol 8, No 3, pp 469-491.

Bowen, J.R. (2003), Islam, Law and Equality in Indonesia: An Anthropology of Public Reasoning, Cambridge University Press, Cambridge.

BPS (Biro Pusat Statistik, Central Bureau of Statistics) (2008), Perkembangan Beberapa Indikator 
Utama Sosial-Ekonomi [Trends of Several Main Socio-Economic Indicators], BPS Katalog 3101015 , website: http://www.bps.go.id/leaflet/booklet_okt08.pdf (accessed 27 July 2009; no longer available online, but readers can apply to the author for a copy).

BPS (2011), 'Sensus penduduk 2010, penduduk menurut wilayah dan agama yang dianut', website: http://sp2010.bps.go.id/index.php/site/tabel?tid=321\&wid=0 (accessed 28 January 2013).

Butt, S. (1999), 'Polygamy and mixed marriage in Indonesia: the application of the Marriage Law in the courts', in Lindsey, T., ed, Indonesia: Law and Society, Federation Press, Sydney, pp 122-144.

Cammack, M. (2009), 'Legal aspects of Muslim-non-Muslim marriage in Indonesia', in Jones, G., et al, eds, Muslim-Non-Muslim Marriage: Political and Cultural Contestations in Southeast Asia, Institute of Southeast Asian Studies, Singapore, pp 102-138.

Chee, H.L., Jones, G.W., and Mohamad, M. (2009), 'Muslim-non-Muslim marriage, rights and the state in Southeast Asia', in Jones, G., et al, eds, Muslim-Non-Muslim Marriage: Political and Cultural Contestations in Southeast Asia, Institute of Southeast Asian Studies, Singapore, pp 130.

Cholil, S. (2009), 'The politico-religious contestation: hardening of the Islamic law on Muslim-nonMuslim marriage in Indonesia', in Jones, G., et al, eds, Muslim-Non-Muslim Marriage: Political and Cultural Contestations in Southeast Asia, Institute of Southeast Asian Studies, Singapore, pp 139-158.

Crouch, M. (2009), 'Religious regulations in Indonesia: failing vulnerable groups', Review of Indonesian and Malaysian Affairs, Vol 43, No 2, pp 53-105.

Feener, R.M. (2007), Muslim Legal Thought in Modern Indonesia, Cambridge University Press, Cambridge.

Gillespie, P. (2007), 'Current issues in Indonesian Islam: analysing the 2005 Council of Indonesian Ulama Fatwa No.7 opposing pluralism, liberalism and secularism', Journal of Islamic Studies, Vol 18, No 2, pp 202-240.

Hoon, C.Y. (2008), Chinese Identity in Post-Suharto Indonesia: Culture, Politics and Media, Sussex Academic Press, Brighton, and Portland, OR.

Husein, F. (2005), Muslim-Christian Relations in the New Order Indonesia: The Exclusivist and Inclusivist Muslims' Perspectives, MizanPustaka, Bandung.

Loewenthal, K.M., MacLeod, A.K., and Cinnirella, M. (2002), 'Are women more religious than men? Gender differences in religious activity among different religious groups in the UK', Personality and Individual Differences, Vol 32, No 1, pp 133-139.

Lukito, R. (2009), 'Trapped between legal unification and pluralism: the Indonesian Supreme Court's decision on interfaith marriage', in Jones, G., et al, eds, Muslim-Non-Muslim Marriage: Political and Cultural Contestations in Southeast Asia, Institute of Southeast Asian Studies, Singapore, pp 33-58.

Mujiburrahman (2006), Feeling Threatened: Muslim-Christian Relations in Indonesia's New Order, Amsterdam University Press, Amsterdam.

Munjid, A. (2013), 'The controversy over “merry Xmas”: where's the fatwa?' The Jakarta Post, 23 December, website: http://www.thejakartapost.com/news/2013/12/23/the-controversy-over-merryxmas-where-s-fatwa.html (accessed 29 January 2014).

Nilan, P., Parker, L., Bennett, L., and Robinson, K. (2011), 'Indonesian youth looking towards the future', Journal of Youth Studies, Vol 14, No 6, pp 709-728.

Parker, L., and Nilan, P. (2013), Adolescents in Contemporary Indonesia, Routledge, London.

Picard, M. (2011), 'From Agama Hindu Bali to Agama Hindu and back: toward a relocalization of the Balinese religion?' in Picard, M., and Madinier, R., eds, The Politics of Religion in Indonesia: Syncretism, Orthodoxy, and Religious Contention in Java and Bali, Routledge, London and New York, pp 117-141.

Seo, M. (2013), 'Falling in love and changing gods', Indonesia and the Malay World, Vol 41, No 119, pp 76-96.

Stark, R. (2002), 'Physiology and faith: addressing the "universal" gender difference in religious commitment', Journal for the Scientific Study of Religion, Vol 41, No 3, pp 495-507.

White, S., and Anshor, M.U. (2008), 'Islam and gender in contemporary Indonesia: public discourses on duties, rights and morality', in Fealy, G., and White, S., eds, Expressing Islam: Religious Life and Politics in Indonesia, ISEAS, Singapore, pp 137-158. 